\title{
Enhanced Detection of Glycans by MALDI-TOF Mass Spectrometry Using a Binary Matrix of 2,5-Dihydroxybenzoic Acid and 2,6-Dihydroxybenzoic Acid
}

\author{
Yunjin Kim, Taehee Kim, Jihyeon Lee, Haeju Im, and Jeongkwon Kim* \\ Department of Chemistry, Chungnam National University, Daejeon, South Korea
}

Received June 23, 2013; Revised June 26, 2013; Accepted June 27, 2013

First published on the web June 30, 2013; DOI: 10.5478/MSL.2013.4.1.38

\begin{abstract}
Glycans released from ovalbumin by PNGase F were analyzed by matrix-assisted laser desorption/ionization time-offlight (MALDI-TOF) mass spectrometry using three different dihydroxybenzoic acid (DHB) matrix systems: 2,5-DHB, 2,6DHB, and a 2,5-DHB/2,6-DHB binary matrix. Relative to the results obtained with the single-component matrices (2,5-DHB or 2,6-DHB), the 2,5-DHB/2,6-DHB binary matrix boasted lower background noise and higher sensitivity. A total of 16 glycan peaks were observed using the 2,5-DHB/2,6-DHB binary matrix, while only 10 and 9 glycan peaks were observed using the 2,5DHB and 2,6-DHB matrices, respectively.
\end{abstract}

Keywords: Glycans, MALDI, PNGase F, ovalbumin, oligosaccharides, dihydroxybenzoic acid

\section{Introduction}

Glycosylation is one of the most common post-translational modifications in biology. ${ }^{1}$ Effective and reliable analytical methods for glycans are important because the products of glycosylation are often present in clinical biomarkers. ${ }^{2}$ Recent developments in mass spectrometry (MS) have provided rapid and sensitive methods for the detection of a variety of glycans. ${ }^{3}$ Among the different matrices used in matrix-assisted laser desorption/ionization time-of-flight (MALDI-TOF) MS, 2,5dihydroxybenzoic acid (2,5-DHB) is one of the most common and is frequently used for analyses of synthetic polymers, ${ }^{4}$ peptides/proteins, ${ }^{5}$ and oligosaccharides. ${ }^{6}$ Recently, 2,6-DHB was introduced as an alternative matrix for the analysis of oligonucleotides, polysaccharides, ${ }^{7}$ and synthetic polymers. ${ }^{4}$ The combination of two matrix materials has been effective in several MALDI-TOF MS analyses. For example, a binary matrix of 2,5DHB and $\alpha$-cyano-4-hydroxycinnamic acid (CHCA) was effectively used to detect peptides and glycoproteins. ${ }^{8}$ Recently, binary matrices of 2,5-DHB/CHCA and 2,5-DHB/sinapinic acid were reported in successful analyses of intact glycoproteins and glycans. ${ }^{9}$

The current study investigated the effectiveness of a new binary matrix composed of 2,5-DHB and 2,6-DHB in analyses of glycans released from ovalbumin by enzymatic cleavage with PNGase F. The mass spectrum acquired with the binary matrix was compared with those obtained using the single matrix materials $(2,5-\mathrm{DHB}$ or $2,6-\mathrm{DHB})$.

\footnotetext{
*Reprint requests to Prof.Jeongkwon Kim
}

E-mail: jkkim48105@cnu.ac.kr

\section{Experimental}

All chemicals were obtained from Sigma-Aldrich (St. Louis, MO, USA) unless otherwise specified. To perform deglycosylation, $2 \mathrm{mg}$ of ovalbumin (catalog number: A5503) was mixed with 1 unit of PNGase F (catalog number: P7367) in $200 \mu \mathrm{L}$ of $50 \mathrm{mM}$ ammonium bicarbonate buffer solution for 2 $\mathrm{h}$ at $37^{\circ} \mathrm{C}$ with gentle mixing. To prepare the $2,5-\mathrm{DHB} / 2,6-\mathrm{DHB}$ binary matrix solution, a mixture of 2,5-DHB $(5 \mathrm{mg})$ and 2,6DHB (5 mg) was dissolved in $1 \mathrm{~mL}$ of $50 \%$ acetonitrile $(\mathrm{ACN})$ in $\mathrm{H}_{2} \mathrm{O}$. For comparison, individual DHB matrices (2,5-DHB and 2,6-DHB) were also prepared to a concentration of $10 \mathrm{mg} /$ $\mathrm{mL}$ in $50 \%$ ACN. To prepare the sample targets for MALDIMS analysis, $0.6 \mu \mathrm{L}$ of the matrix solution was loaded and allowed to dry on a MALDI plate and covered with $1 \mu \mathrm{L}$ of the mixed sample/matrix solution (1:1, v/v). MALDI spectra were obtained on a Voyager MALDI-TOF mass spectrometer (Applied Biosystems) in reflection positive ion mode.

\section{Results and Discussion}

Improvements realized with the 2,5-DHB/2,6-DHB binary matrix

Figure 1 shows MALDI mass spectra of the glycans released from ovalbumin using PNGase F. Note that the highest number of glycans were detected using the binary matrix of 2,5-DHB/2,6DHB. Table 1 summarizes the glycans identified in the current investigation along with the published results of other researchers. A total of 16 glycans were identified using the 2,5-DHB/2,6-DHB binary matrix, while only 10 and 9 glycans were identified when 2,5-DHB and 2,6-DHB were used independently, respectively. Harvey et al. identified 13 glycans from MALDI-TOF mass spectra 
obtained from HPLC-separated ovalbumin with a 2,5-DHB matrix. ${ }^{10}$ Snovida et al. used a 2,5-DHB/N,N-dimethylaniline

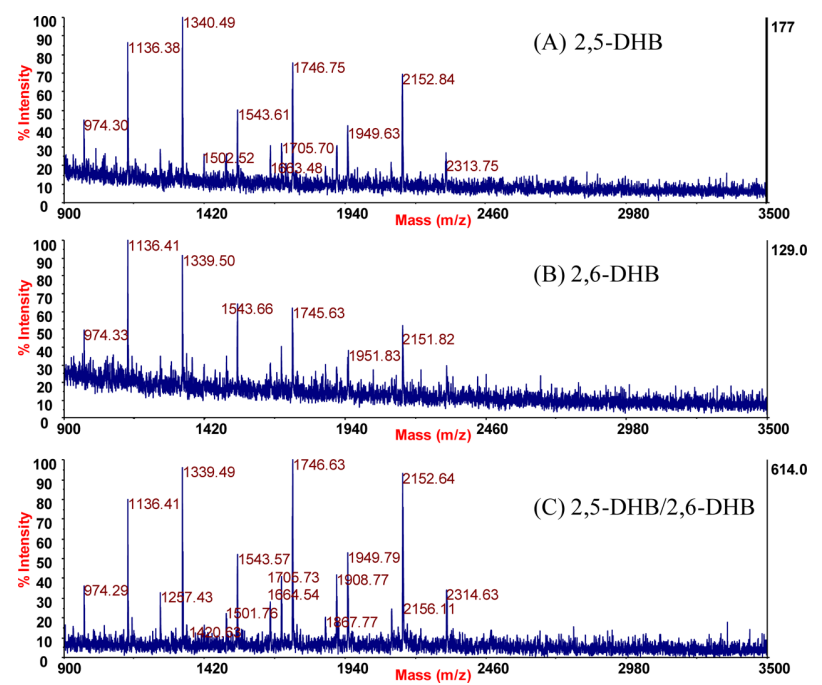

Figure 1. MALDI mass spectra of glycans released from ovalbumin obtained using (A) 2,5-DHB, (B) 2,6-DHB, and (C) 2,5-DHB/2,6-DHB matrices.
(DMA) binary matrix to improve the MALDI detection efficiency of glycans. In that study, 11 glycans released from ovalbumin by PNGase F were identified, while no glycans were identified when using a 2,5-DHB matrix. ${ }^{11}$ Overall, the number of glycans observed using the 2,5-DHB/2-6-DHB binary matrix was higher than those detected using any other published matrix systems, including 2,5DHB, 2,6-DHB, and 2,5-DHB/DMA.

\section{Effects of other additives}

The addition of phosphoric acid has been reported to enhance the signal intensities of phosphopeptides ${ }^{12}$ and nonphosphopeptides. $^{13}$ Therefore, the addition of phosphoric acid was also investigated with regard to glycan analyses. No improvements were observed in any of the matrix systems used in the current study (2,5-DHB, 2,6-DHB, and 2,5-DHB/ 2,6-DHB). This is thought to be due to the fact that the current glycan detection requires sodium ion adducts in order to be detected by MALDI-MS. The effect of adding trifluoroacetic acid (TFA) to the matrix solutions was also investigated; no improvement was observed with all three matrix systems. Because the sodium adducts are the detected entity in positive ion mode MALDI-MS analysis of glycans, sodium cations, as

Table 1. Summary of the identified glycans obtained from the deglycosylation of ovalbumin

\begin{tabular}{|c|c|c|c|c|c|c|c|}
\hline \multirow[b]{2}{*}{ Theoretical $\mathrm{m} / \mathrm{z}$ values } & \multirow[b]{2}{*}{ Structures } & \multirow[b]{2}{*}{ Elemental Composition } & \multicolumn{3}{|c|}{ "Current Investigation } & \multicolumn{2}{|c|}{ Literature } \\
\hline & & & 2,5-DHB & 2,6-DHB & $\begin{array}{c}\text { Binary } \\
\text { matrix }^{a}\end{array}$ & $2,5-\mathrm{DHB}^{\mathrm{b}) 10}$ & $\begin{array}{c}2,5-\mathrm{DHB} / \\
\mathrm{DMA}^{\mathrm{c}) 11}\end{array}$ \\
\hline 974.34 & $\mathrm{Hex}_{2}(\mathrm{HexNAc})_{3} \mathrm{Na}$ & $\mathrm{C}_{36} \mathrm{O}_{26} \mathrm{~N}_{3} \mathrm{H}_{61} \mathrm{Na}$ & $\mathrm{O}$ & $\mathrm{O}$ & $\mathrm{O}$ & & \\
\hline 1136.40 & $\mathrm{Hex}_{3}(\operatorname{HexNAc})_{3} \mathrm{Na}$ & $\mathrm{C}_{42} \mathrm{O}_{31} \mathrm{~N}_{3} \mathrm{H}_{71} \mathrm{Na}$ & $\mathrm{O}$ & $\mathrm{O}$ & $\mathrm{O}$ & & $\mathrm{O}$ \\
\hline 1257.42 & $\mathrm{Hex}_{5}(\mathrm{HexNAc})_{2} \mathrm{Na}$ & $\mathrm{C}_{46} \mathrm{O}_{36} \mathrm{~N}_{2} \mathrm{H}_{78} \mathrm{Na}$ & & & $\mathrm{O}$ & $\mathrm{O}$ & \\
\hline 1339.48 & $\mathrm{Hex}_{3}(\operatorname{HexNAc})_{4} \mathrm{Na}$ & $\mathrm{C}_{50} \mathrm{O}_{36} \mathrm{~N}_{4} \mathrm{H}_{84} \mathrm{Na}$ & $\mathrm{O}$ & $\mathrm{O}$ & $\mathrm{O}$ & & $\mathrm{O}$ \\
\hline 1419.48 & $\mathrm{Hex}_{6}(\mathrm{HexNAc})_{2} \mathrm{Na}$ & $\mathrm{C}_{52} \mathrm{O}_{41} \mathrm{~N}_{2} \mathrm{H}_{88} \mathrm{Na}$ & & & $\mathrm{O}$ & $\mathrm{O}$ & \\
\hline 1460.50 & $\mathrm{Hex}_{5}(\mathrm{HexNAc})_{3} \mathrm{Na}$ & $\mathrm{C}_{54} \mathrm{O}_{41} \mathrm{~N}_{3} \mathrm{H}_{91} \mathrm{Na}$ & & & & $\mathrm{O}$ & \\
\hline 1501.53 & $\mathrm{Hex}_{4}(\mathrm{HexNAc})_{4} \mathrm{Na}$ & $\mathrm{C}_{56} \mathrm{O}_{41} \mathrm{~N}_{4} \mathrm{H}_{94} \mathrm{Na}$ & $\mathrm{O}$ & & $\mathrm{O}$ & $\mathrm{O}$ & $\mathrm{O}$ \\
\hline 1542.56 & $\mathrm{Hex}_{3}(\mathrm{HexNAc})_{5} \mathrm{Na}$ & $\mathrm{C}_{58} \mathrm{O}_{41} \mathrm{~N}_{5} \mathrm{H}_{97} \mathrm{Na}$ & $\mathrm{O}$ & $\mathrm{O}$ & $\mathrm{O}$ & $\mathrm{O}$ & $\mathrm{O}$ \\
\hline 1581.53 & $\mathrm{Hex}_{7}(\mathrm{HexNAc})_{2} \mathrm{Na}$ & $\mathrm{C}_{58} \mathrm{O}_{46} \mathrm{~N}_{2} \mathrm{H}_{98} \mathrm{Na}$ & & & & $\mathrm{O}$ & \\
\hline 1622.55 & $\mathrm{Hex}_{6}(\mathrm{HexNAc})_{3} \mathrm{Na}$ & $\mathrm{C}_{60} \mathrm{O}_{46} \mathrm{~N}_{3} \mathrm{H}_{101} \mathrm{Na}$ & & & & $\mathrm{O}$ & \\
\hline 1663.58 & $\mathrm{Hex}_{5}(\mathrm{HexNAc})_{4} \mathrm{Na}$ & $\mathrm{C}_{62} \mathrm{O}_{46} \mathrm{~N}_{4} \mathrm{H}_{104} \mathrm{Na}$ & & & $\mathrm{O}$ & $\mathrm{O}$ & \\
\hline 1704.61 & $\mathrm{Hex}_{4}(\mathrm{HexNAc})_{5} \mathrm{Na}$ & $\mathrm{C}_{64} \mathrm{O}_{46} \mathrm{~N}_{5} \mathrm{H}_{107} \mathrm{Na}$ & & & $\mathrm{O}$ & $\mathrm{O}$ & $\mathrm{O}$ \\
\hline 1745.64 & $\mathrm{Hex}_{3}(\operatorname{HexNAc})_{6} \mathrm{Na}$ & $\mathrm{C}_{66} \mathrm{O}_{46} \mathrm{~N}_{6} \mathrm{H}_{110} \mathrm{Na}$ & $\mathrm{O}$ & $\mathrm{O}$ & $\mathrm{O}$ & $\mathrm{O}$ & $\mathrm{O}$ \\
\hline 1866.66 & $\mathrm{Hex}_{5}(\mathrm{HexNAc})_{5} \mathrm{Na}$ & $\mathrm{C}_{70} \mathrm{O}_{51} \mathrm{~N}_{5} \mathrm{H}_{117} \mathrm{Na}$ & & & $\mathrm{O}$ & $\mathrm{O}$ & \\
\hline 1907.69 & $\mathrm{Hex}_{4}(\mathrm{HexNAc})_{6} \mathrm{Na}$ & $\mathrm{C}_{72} \mathrm{O}_{51} \mathrm{~N}_{6} \mathrm{H}_{120} \mathrm{Na}$ & & & $\mathrm{O}$ & $\mathrm{O}$ & $\mathrm{O}$ \\
\hline 1948.71 & $\mathrm{Hex}_{3}(\mathrm{HexNAc})_{7} \mathrm{Na}$ & $\mathrm{C}_{74} \mathrm{O}_{51} \mathrm{~N}_{7} \mathrm{H}_{123} \mathrm{Na}$ & $\mathrm{O}$ & $\mathrm{O}$ & $\mathrm{O}$ & & $\mathrm{O}$ \\
\hline 2028.71 & $\mathrm{Hex}_{6}(\mathrm{HexNAc})_{5} \mathrm{Na}$ & $\mathrm{C}_{76} \mathrm{O}_{56} \mathrm{~N}_{5} \mathrm{H}_{127} \mathrm{Na}$ & & & & $\mathrm{O}$ & \\
\hline 2110.77 & $\mathrm{Hex}_{4}(\mathrm{HexNAc})_{7} \mathrm{Na}$ & $\mathrm{C}_{80} \mathrm{O}_{56} \mathrm{~N}_{7} \mathrm{H}_{133} \mathrm{Na}$ & $\mathrm{O}$ & $\mathrm{O}$ & $\mathrm{O}$ & & $\mathrm{O}$ \\
\hline 2151.79 & $\mathrm{Hex}_{3}(\mathrm{HexNAc})_{8} \mathrm{Na}$ & $\mathrm{C}_{82} \mathrm{O}_{56} \mathrm{~N}_{8} \mathrm{H}_{136} \mathrm{Na}$ & $\mathrm{O}$ & $\mathrm{O}$ & $\mathrm{O}$ & & $\mathrm{O}$ \\
\hline 2313.85 & $\mathrm{Hex}_{4}(\mathrm{HexNAc})_{8} \mathrm{Na}$ & $\mathrm{C}_{88} \mathrm{O}_{61} \mathrm{~N}_{8} \mathrm{H}_{146} \mathrm{Na}$ & $\mathrm{O}$ & $\mathrm{O}$ & $\mathrm{O}$ & & $\mathrm{O}$ \\
\hline \multicolumn{3}{|c|}{ Number of identified glycans } & 10 & 9 & 16 & 13 & 11 \\
\hline
\end{tabular}

a) Mixture of 2,5-DHB and 2,6-DHB b) Glycans were released from purified ovalbumin with PNGase F using an in-gel release technique. c) DMA: N,N-dimethylaniline 
NaTFA or $\mathrm{NaCl}$, are often added to improve detection. ${ }^{6}$ However, the addition of NaTFA or $\mathrm{NaCl}$ to the sample solutions herein did not improve detection.

\section{Reasons for enhanced signals}

Uniform sample distribution within the MALDI sample spot, due to homogeneous crystallization, ${ }^{9}$ is believed to be the primary factor in realizing the observed improvement in glycan detection efficiency. In addition, synergistic effects of 2,5-DHB and 2,6-DHB, both of which have been reported as matrix materials in glycan analyses, are believed to enhance detection efficiency.

\section{Conclusion}

Various matrix materials (2,5-DHB, 2,6-DHB, and 2,5-DHB/ 2,6-DHB) were evaluated for their effectiveness in MALDI-TOF MS analyses of glycans. A 2,5-DHB/2,6-DHB binary matrix provided better performance than single matrices composed of 2,5DHB or 2,6-DHB.

\section{Acknowledgements}

The authors acknowledge support for this work by Basic Science Research Program through the National Research Foundation of Korea (NRF) funded by the Ministry of Education, Science and Technology (2010-0010776).

\section{References}

1. An, H. J.; Peavy, T. R.; Hedrick, J. L.; Lebrilla, C. B. Anal. Chem. 2003, 75, 5628.

2. Hua, S.; Oh, M. J.; An, H. J. Mass Spectrom. Lett. 2013, 4, 10.

3. Harvey, D. J. Rapid Commun. Mass Spectrom. 1993, 7 , 614.

4. Lee, A.; Yang, H. J.; Kim, Y.; Kim, J. Bull. Korean Chem. Soc. 2009, 30, 1127.

5. Shin, S.; Yang, H. J.; Kim, J. Anal. Biochem. 2011, 414, 125.

6. Park, E.; Yang, H.; Kim, Y.; Kim, J. Food Chem. 2012, 134, 1658.

7. Jessome, L.; Hsu, N. Y.; Wang, Y. S.; Chen, C. H. Rapid Commun. Mass Spectrom. 2008, 22, 130.

8. Laugesen, S.; Roepstorff, P. J. Am. Soc. Mass Spectrom. 2003, 14, 992.

9. Lastovickova, M.; Chmelik, J.; Bobalova, J. Int. J. Mass Spectrom. 2009, 281, 82.

10. Harvey, D. J.; Wing, D. R.; Kuster, B.; Wilson, I. B. J. Am. Soc. Mass Spectrom. 2000, 11, 564.

11. Snovida, S. I.; Rak-Banville, J. M.; Perreault, H. J. Am. Soc. Mass Spectrom. 2008, 19, 1138.

12. Kjellstrom, S.; Jensen, O. N. Anal. Chem. 2004, 76, 5109.

13. Park, S.; Kim, T.; Lee, J.; Seo, M.; Kim, J. Rapid Commun. Mass Spectrom. 2013, $27,842$. 